\title{
Role of mangroves as nurseries for French grunt Haemulon flavolineatum and schoolmaster Lutjanus apodus assessed by otolith elemental fingerprints
}

\author{
Ivan Mateo ${ }^{1, *}$, Edward G. Durbin ${ }^{2}$, Richard S. Appeldoorn ${ }^{3}$, Aaron J. Adams ${ }^{4}$, \\ Francis Juanes ${ }^{5}$, Richard Kingsley ${ }^{2}$, Peter Swart ${ }^{6}$, Daisy Durant ${ }^{7}$
}

\footnotetext{
${ }^{1}$ Department of Fisheries, Animal and Veterinary Sciences, University of Rhode Island, Kingston, Rhode Island 02881, USA

${ }^{2}$ Graduate School of Oceanography, University of Rhode Island, Narragansett, Rhode Island 02882, USA ${ }^{3}$ Department of Marine Sciences, University of Puerto Rico, Mayaguez, Puerto Rico 00681

${ }^{4}$ Mote Marine Laboratory, Pineland, Florida 33945, USA

${ }^{5}$ Department of Natural Resources Conservation, University of Massachusetts-Amherst, Amherst, Massachusetts 01003, USA ${ }^{6}$ Division of Marine Geology and Geophysics, Rosenstiel School of Marine and Atmospheric Science, University of Miami, Miami, Florida 33149, USA

${ }^{7}$ Narragansett Bay Research Reserve, PO Box 151, Prudence Island, Rhode Island 02872, USA
}

\begin{abstract}
Juvenile French grunt Haemulon flavolineatum and schoolmaster Lutjanus apodus were captured in mangrove and seagrass stations in St. Croix, and Puerto Rico in 2006 and 2007 to determine whether areas for juvenile fish can be discriminated by means of otolith chemistry. Concentrations of 16 elements were determined in 0-group fish otoliths using laser ablation-inductively coupled plasma mass spectrometry. Two stable isotopes, $\delta^{18} \mathrm{O}$ and $\delta^{13} \mathrm{C}$, in French grunt and schoolmaster otoliths were also analyzed. Multi-elemental signatures for both species differed significantly $(p<$ 0.001) among mangrove and seagrass stations within both islands. Furthermore, concentrations of 6 elements ( $\mathrm{Sr}, \mathrm{Ba}, \mathrm{Cu}, \mathrm{Mg}, \mathrm{Co}, \mathrm{Na}$ ) as well as $\delta^{18} \mathrm{O}$ and $\delta^{13} \mathrm{C}$ for both species within each year differed significantly among mangrove and seagrass stations within islands $(p<0.001)$. Classification success for French grunt and schoolmaster juvenile areas within St. Croix across years ranged from 87 to $92 \%$ and from 76 to $77 \%$, respectively, whereas in Puerto Rico, classification success for French grunt and schoolmaster for the 2 years ranged from 80 to $84 \%$ and 84 to $87 \%$, respectively. Classification success between mangrove and seagrass habitats (stations combined) in Puerto Rico for French grunt ranged from 84 to $91 \%$, and for schoolmaster ranged from 94 to $99 \%$. In St. Croix, classification success for French grunt was 95 to 96 \%, and for schoolmaster was 86 to $89 \%$. The percentages of French grunt subadults collected from forereef stations in St. Croix, identified as having resided as juveniles in mangrove habitats in 2006 and 2007, were 40 and $68 \%$, respectively, while for Puerto Rico, these percentages were 70 and $74 \%$. By contrast, for schoolmaster almost $100 \%$ of all fish in both islands resided as juveniles in mangrove habitats in both years. This study contains the first direct evidence of postsettlement fish movement connecting mangrove habitats to the reef using otolith chemistry.
\end{abstract}

KEY WORDS: Fish nursery Otolith chemistry $\cdot$ Stable isotopes $\cdot$ Natural tags $\cdot$ Haemulon flavolineatum Lutjanus apodus $\cdot$ Juvenile habitat

\section{INTRODUCTION}

Many marine fish species have juvenile and adult life stages that occupy spatially separated habitats. The juveniles often recruit to nearshore habitats where they reside for months to years before migrating to offshore habitats to join the adult population (Beck et al. 2001, Gillanders et al. 2003). For many species with this life history pattern the juveniles recruit to more than one type of nearshore habitat, for example, man- 
grove and seagrass meadows, and those different habitats are likely to vary in quality (Beck et al. 2001, Gillanders et al. 2003, Mumby et al. 2004). Determining the relative value of various nursery areas is important to both understanding the ecological roles of the different juvenile habitats and managing harvested fish populations and coastal resources. Identification of nursery habitats is particularly important when some of the nearshore habitats used by juvenile fish are vulnerable to degradation or loss (Beck et al. 2001, Adams \& Ebersole 2002, Mumby et al. 2004, Gillanders 2005). Otolith chemistry is a powerful tool used to investigate movements and life history of fishes (Campana 1999, Gillanders et al. 2003, Elsdon et al. 2008). Chemical habitat tags in the otoliths of juvenile fish have been used to differentiate individuals from different estuarine or riverine systems (Thorrold et al. 1998a,b, Gillanders \& Kingsford 2000, Gillanders $2002 \mathrm{~b}$ ) and alternative types of nearshore habitats, including estuary versus rocky reef (Gillanders \& Kingsford 1996) and estuary versus exposed coastal habitats (Yamashita et al. 2000, Forrester \& Swearer 2002, Fodrie \& Herzka 2008). In addition, through chemical analysis of the juvenile core of adult otoliths, the habitat tag has been used to determine the proportions of the adult fish population that resided in different juvenile habitats (Yamashita et al. 2000, Thorrold et al. 2001, Gillanders 2002a, Kraus \& Secor 2005, Fodrie \& Herzka 2008).

The French grunt Haemulon flavolineatum and the schoolmaster Lutjanus apodus are economically important species that occur in the western Atlantic Ocean and range from Bermuda to Brazil, including the Caribbean Sea. They occur in large schools on rocky and coral reefs to $60 \mathrm{~m}$ depth. Juveniles $(<2 \mathrm{~cm})$ settle from the plankton after 20 to $30 \mathrm{~d}$ in a highly aggregated pattern (Brothers \& McFarland 1981, McFarland et al. 1985, Shulman 1985, Lindeman 1997). The majority (95\%) of these juvenile fish settle into seagrass and mangrove habitats while about $5 \%$ settle onto structures such as rubble or coral heads (Shulman \& Ogden 1987, Rooker \& Dennis 1991, Nagelkerken et al. 2000a, Aguilar-Perera \& Appeldoorn 2007). After a few weeks to months the small juveniles migrate to join schools of intermediate-sized individuals present in mangrove habitats (Rooker \& Dennis 1991, Rooker 1995, Appeldoorn et al. 1997, Nagelkerken et al. 2000a,b,c, Mumby et al. 2004), or back-reef structures, usually patch reefs (Ogden \& Ehrlich 1977, Brothers \& McFarland 1981, Mateo \& Tobias 2001, 2004, Adams \& Ebersole 2002). Large juveniles eventually emigrate from these schools, and are presumed to move to forereef habitats, where they reside individually or in small groups (Appeldoorn et al. 1997, Cocheret de la Morinière et al. 2002). Adults of most French grunt and schoolmaster typically form schools of a few to several hundred fish on coral reefs by day and feed in adjacent seagrass and mangrove areas by night (Appeldoorn et al. 1997, Nagelkerken et al. 2000a, Cocheret de la Morinière et al. 2002, Nagelkerken \& van der Velde 2002, Mumby et al. 2004). However, studies about the reproductive strategies as well as the population structure of these 2 species are lacking.

The goals of the present study are to (1) investigate the utility of using the elemental composition of otoliths as naturally occurring habitat tags to determine habitat linkages in tropical nearshore ecosystems for juvenile and adult fish populations, and (2) evaluate the contribution of mangrove and seagrass habitats to adult fish populations of offshore reefs. The specific questions that this study addresses are: (1) Can tropical fish settlement and juvenile areas be identified by chemical signatures from otolith microchemistry? (2) Are spatial differences in the chemical signatures from tropical juvenile fish within juvenile areas consistent temporally? (3) What proportion of subadult French grunt and schoolmaster use mangrove and seagrass habitats as juveniles?

\section{MATERIALS AND METHODS}

Sampling methods. In St. Croix, US Virgin Islands, 0-group juvenile French grunts and schoolmasters were collected from 2 mangrove (Altona Lagoon and Salt River) and 3 seagrass habitats (Teague Bay, Turner Hole and Great Pond) during May in 2006 and 2007 (Fig. 1). Distances between stations on the north coast of St. Croix were about 8 to $16 \mathrm{~km}$, whereas on the south coast the distance between stations was $5 \mathrm{~km}$. Fish were collected with 10 fish traps and a beach seine net. The fish traps were rectangular $(92 \times 57 \times$ $19 \mathrm{~cm}$ ) and made from vinyl-coated wire with $1.3 \mathrm{~cm}$ square mesh. Each trap was baited with $\sim 400 \mathrm{~g}$ of herring Clupea harengus and set for $2 \mathrm{~d}$. The beach seine measured $15.24 \times 1.22 \mathrm{~m}$ and had $1.3 \mathrm{~cm}$ stretch mesh. From 20 to 25 fish, 3 to $12 \mathrm{~cm}$ fork length (FL), were caught at each station (no French grunt were caught at Great Pond and no schoolmaster at Turner Hole). Sampled fish were kept frozen until they were dissected to remove the otoliths.

In Puerto Rico, 0-group juvenile fish were collected in La Parguera Bay from 1 mangrove station (Bahia Montalva) and 2 seagrass stations (Corral and El Palo), and in Guayanilla Bay from 2 mangrove stations (Punta Guayanilla and Maria Langa) (Fig. 1), from June and September 2006 and in June 2007. Distances between stations within La Parguera were about 3 to $5 \mathrm{~km}$, whereas distance between the 2 bays (Guayanilla Bay and La Parguera) was $28 \mathrm{~km}$. Both fish traps 
and a seine were used as described above for sampling in St. Croix. From 20 to 25 schoolmasters and French grunts, 3 to $12 \mathrm{~cm} \mathrm{FL,} \mathrm{were} \mathrm{caught} \mathrm{at} \mathrm{each} \mathrm{station} \mathrm{(ex-}$ cept for Guayanilla Bay where no French grunt were
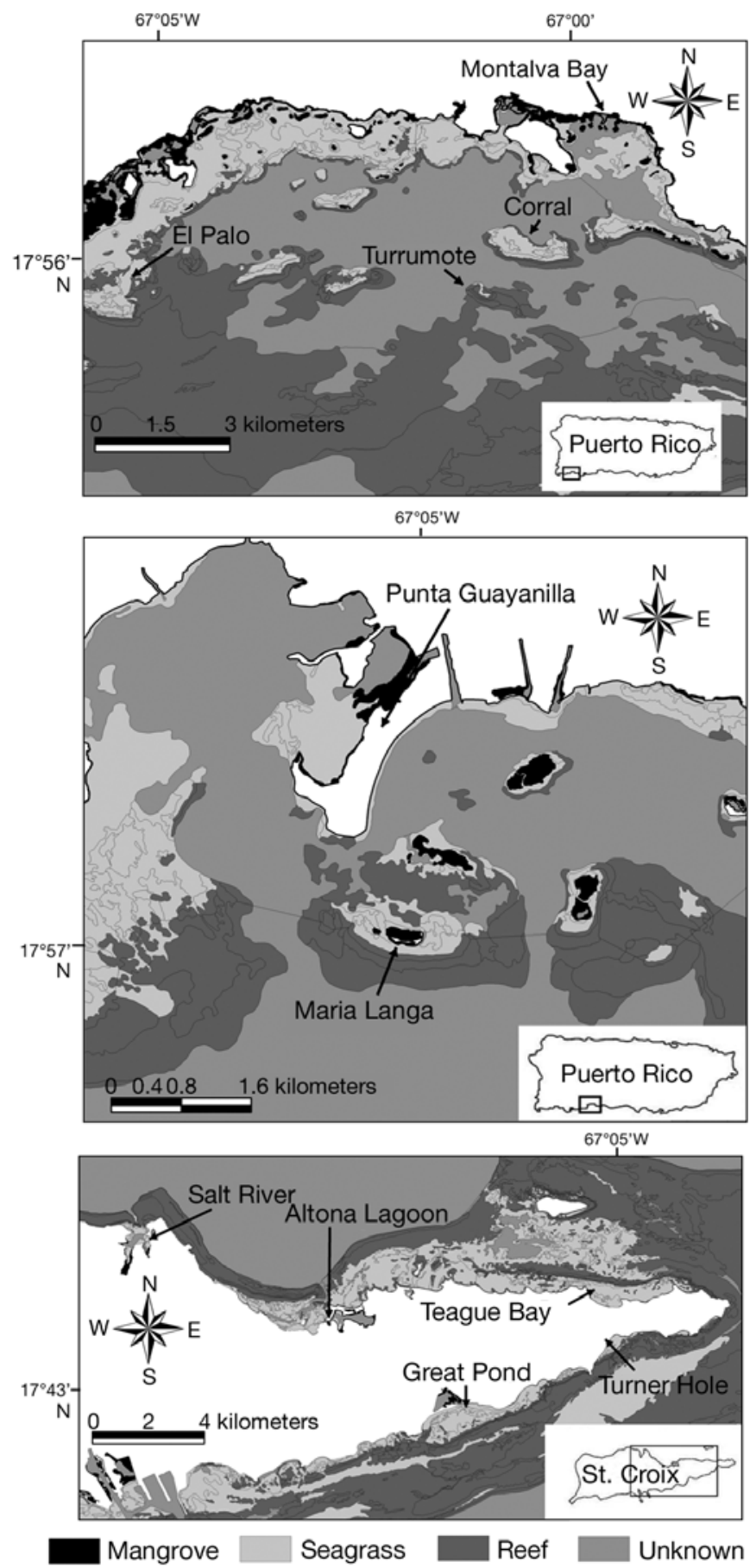

Fig. 1. Study stations selected to collect juvenile French grunts Haemulon flavolineatum and schoolmasters Lutjanus apodus in (a) La Parguera, Puerto Rico, (b) Punta Guayanilla, Puerto Rico, and (c) St. Croix. Modified from Kendall et al. (2001) caught, and Maria Langa where no schoolmaster were caught) and kept frozen until they were dissected to remove the otoliths.

We investigated connectivity in only a few specific locations where we found sufficient numbers of subadults on nearby reefs close to mangrove and seagrass habitats for comparison. We felt that these locations were ideal to study connectivity because (1) when we examined other nearby reefs adjacent to our mangrove study sites, there were few subadult individuals to collect and (2) some of these reefs constantly receive heavy fishing pressure. Therefore, we felt that if we included 2 years of data from 1 offshore reef site from 2 different locations (St. Croix and Puerto Rico), this would provide a better representation of the contribution of seagrass and mangrove habitats as fish nurseries to offshore reef fish populations. Subadult schoolmasters and French grunts were collected from reefs adjacent to Salt River mangrove lagoon in St. Croix, and Turrumote reef in the La Parguera, Puerto Rico, during the months of May and June 2007 and November 2008. This latter reef is adjacent to Bahia Montalva (mangrove station) and Corral (seagrass station). Fish were caught by spearfishing. Schoolmasters between 15 and $20 \mathrm{~cm}$ FL and French grunts from 12 to $15 \mathrm{~cm}$ FL were kept for analysis. These size ranges represent approximately $1 \mathrm{yr}$ old fish (Billings \& Munro 1974, Thompson \& Munro 1983, Claro \& García-Arteaga 1994) and would have been juveniles during the 2006 sampling season. Age was subsequently verified by examining annual bands and daily increments in otoliths at the National Marine Fisheries Service, Beaufort Laboratory (Mateo 2009, J. Potts pers. comm.). Fish were frozen before otoliths were removed.

Otolith chemistry. Fork length of each fish was measured before fish were dissected to remove the otoliths. Both left (for trace metals) and right (for stable isotopes) sagittal otoliths were removed, cleaned of endolymphatic tissue, rinsed 3 times with Milli-Q water and allowed to dry in a Class 100 laminar flow hood. Samples were placed in acid-washed $2.5 \mathrm{ml}$ snap-cap containers. Each otolith was then measured under an Olympus MX-51 transmitted-light microscope at $400 \times$ using image analysis software (ImagePro 6.1), and weighed ( $\pm 0.01 \mathrm{mg})$ on a Thermo Cahn microbalance. A total of 192 otoliths from juveniles were prepared for chemical analyses (French grunt, $\mathrm{N}=96$; schoolmaster, $\mathrm{N}=96$ ) for 2006. In 2007, 186 otoliths from juveniles were also prepared for chemical analyses (French grunt, $\mathrm{N}=96$; schoolmaster, $\mathrm{N}=90$ ). A total of 93 otoliths from subadults were prepared for chemical analyses (French grunt, $\mathrm{N}=48$; schoolmaster, $N=45$ ) for 2007. In 2008, 96 otoliths from juveniles were also prepared for chemical analyses (French grunt, $\mathrm{N}=48$; schoolmaster, $\mathrm{N}=48$ ). 
Otoliths for trace elemental analysis were embedded in Three System Epoxy using flat embedding silicon rubber molds (Pelco \#105) and left for $2 \mathrm{~d}$ while the epoxy hardened. Transverse thin sections of $400 \mu \mathrm{m}$ were made with a Buehler low speed saw. These sections were mounted on a petrographic slide with thermoplastic glue and ground to the core in the sagittal plane with successively finer lapping film (30, 15, 9 and $3 \mu \mathrm{m}$ ) (Mateo 2009). The sectioned otoliths were ultrasonically cleaned in ultrapure water for $5 \mathrm{~min}$ to remove surface contamination and left to dry for $24 \mathrm{~h}$ in a laminar flow hood. These slides were then stored in petrographic slide boxes until chemical analysis could be performed.

Trace elemental concentrations were analyzed with laser ablation inductively coupled plasma mass spectrometry (LA-ICPMS) (Thermo X-Series II Quadrupole ICP-MS coupled with a UPS 213 Nd:Yag, New Wave Technologies Laser). Before microchemical analysis, otolith increment number and width was analyzed (Image-Pro image analysis software) so that we could sample trace metals in the immediate post-settlement regions of the otolith in juvenile and adult fish. A sharp decline in the increment widths after $30 \mathrm{~d}$, which was seen in both schoolmaster and French grunt, was used as a reference point for the division between larval and postsettlement increments (see Lindeman 1997, Shaw 1997). Before analysis, the area was pre-ablated to reduce surface contamination. Two replicate $40 \mu \mathrm{m}$ diameter spots in the postsettlement zone of each otolith were sampled with the laser operating at $10 \mathrm{~Hz}$, in time-resolved analyses where background values were taken for $30 \mathrm{~s}$ and then $30 \mathrm{~s}$ of ablation analyses were collected. The resolution of the $40 \mu \mathrm{m}$ diameter spots represents about 4 to $6 \mathrm{~d}$ of life for these fishes (Mateo 2009). Initially we examined 16 elements ( $\mathrm{Li}$, $\mathrm{Na}, \mathrm{Mg}, \mathrm{Ca}, \mathrm{Mg}, \mathrm{Mn}, \mathrm{Co}, \mathrm{Cu}, \mathrm{S}, \mathrm{Al}, \mathrm{Se}, \mathrm{Rb}, \mathrm{Sr}, \mathrm{Ba}, \mathrm{Pb}$ and U). Seven elements ( $\mathrm{Na}, \mathrm{Ca}, \mathrm{Mg}, \mathrm{Co}, \mathrm{Cu}, \mathrm{Ba}$, and $\mathrm{Sr}$ ) were consistently detectible above background levels and were used for subsequent data analysis. Analytical results are expressed as molar ratios with respect to calcium.

The NIST 612 glass standard (US Department of Commerce, National Institute of Standards and Technology) was used as a standard for calculation of otolith elemental concentrations. The stability of laser conditions was evaluated by examining the relative standard deviation (RSD) of target elements in the NIST 612 glass standards. The day-to-day precision on the analyte/calcium ratio from this standard is estimated at $20 \%( \pm 5 \% \mathrm{RSD})$, depending on which isotope is the analyte. This parameter was determined by averaging 30 analyses of NIST 612 glass standard that was ablated routinely each day the sample otoliths were analyzed. The limits of detection (LOD, all in $\mu \mathrm{mol} \mathrm{g}^{-1}$ ) were as follows: $\mathrm{Na}$ 6.1214; $\mathrm{Mg}$ 0.0593; Ca 0.1135; Sr 0.0036; Ba 0.0003; Co 0.0167; $\mathrm{Cu}$ 0.0271. The LODs were calculated as 3 times the $\mathrm{SD}$ of the background measurement of the isotope of interest measured in the sample otolith divided by the sensitivity (in counts per second [cps] $\mathrm{mmol}^{-1} \mathrm{~g}^{-1}$ ) measured in the NIST 612 glass standard.

Stable isotope analysis. For inorganic ${ }^{13} \mathrm{C}$ and ${ }^{18} \mathrm{O}$ stable isotope analysis of young-of-the-year (YOY) fish, the right sagittal otoliths were ground to powder with mortar and pestle in a Class 100 laminar flow hood and the powder placed in acid-washed $2.5 \mathrm{ml}$ snap-cap containers. For 1st yr subadults, the thin sections of each otolith were attached to a microscope slide and a computer-driven micromilling machine (Woods Hole Oceanographic Institution [WHOI], Mclean Laboratory) was used to free the juvenile core that represents the first year of growth from the surrounding otolith. This core material was then ground and placed in acid-washed $2.5 \mathrm{ml}$ snap-cap containers. The stable carbon and oxygen isotopic composition of these otolith samples were determined using an automated carbonate device (Kiel III) attached to a Delta-plus stable isotope mass spectrometer. Data are expressed in $\delta$ notation relative to Vienna Peedee Belemnite (V-PDB). Data have been corrected for the usual isobaric interferences. External precision, calculated from replicate analyses of an internal laboratory calcite standard, was $0.04 \%$ for $\delta^{13} \mathrm{C}$ and $0.08 \%$ o for $\delta^{18} \mathrm{O}$.

Statistical analysis. Two-way ANOVA was used to test for differences in fish size among stations and years for both species. We also examined relationships between otolith weight and otolith elemental composition and isotopic signatures with analysis of covariance (ANCOVA). If there was a significant relationship, we removed the effect of size (otolith weight used as a proxy for fish size) to ensure that differences in fish size among samples did not confound any site-specific differences in otolith chemistry. Concentrations of element were weight-detrended by subtracting the product of the common within-group linear slope times the otolith weight from the observed concentration (Campana et al. 2000).

To detect differences in the concentrations of particular elements and multi-element fingerprints among stations, habitats and between years, ANOVA and multivariate analyses of variance (MANOVA) were performed using stations nested within habitats. Pillai's trace was chosen as the test statistic because it is more robust than other multivariate statistics tests (e.g. Wilke's Lamda, Hotteling's T) for small sample sizes, unequal cell sizes and situations in which covariances are not homogeneous. Tukey's Honestly Significant Difference (HSD) test was used 
to detect a posteriori differences among means $(\mathrm{p}<$ 0.05). Before statistical testing, residuals were examined for normality and homogeneity among stations. To meet model assumptions, all analyses were performed on natural log-transformed data $(\ln [x+1])$. Quadratic discriminant function analyses (QDFA) was chosen instead of linear discriminant function analysis as it does not require homogeneity of within-group covariance matrices (Quinn \& Keough 2002). QDFA were used to visualize spatial differences within stations and years and examine classification success for juveniles from different stations or habitats across years. Classification success was the percentage of fish that were correctly assigned to their actual region given the information on location where the fish was collected and the chemical signature of each fish. Cross validations were performed by using jackknife ('leave one out') procedures in Systat.

A maximum-likelihood-based analysis was used to determine the proportion of subadult fish originating from the different nursery habitats. The maximum likelihood estimator was chosen because it performs better than classification-based estimators and provides maximum discriminatory power in mixed stock situations (Millar 1987, 1990). In our study, the chemical and isotopic signatures of the post-settlement region in the otoliths of the schoolmaster and French grunt juveniles captured in seagrass and mangrove habitats on La Parguera, Puerto Rico, and Salt River, St. Croix, in 2006 and 2007 were used as database references and the elemental and isotopic signatures of subadult schoolmasters and French grunts captured in nearby reefs in 2007 and 2008 were considered as the unknown mixed data set. Contribution per unit area was calculated by dividing the proportion of fish originating from a habitat type by its area (Kraus \& Secor 2005, Dahlgren et al. 2006). Actual habitat areas are as follows: in Puerto Rico, mangrove in Montalva Bay = $3.7 \mathrm{~km}^{2}$, seagrass in Corral $=1.5 \mathrm{~km}^{2}$ (Aguilar-Perera \& Appeldoorn 2007); in St. Croix, mangrove in Salt River $=0.12 \mathrm{~km}^{2}$, seagrass in Salt River $=0.21 \mathrm{~km}^{2}$ (Kendall et al. 2005).

\section{RESULTS}

\section{Size distribution}

Mean FL of juvenile French grunts collected at each station varied from 3.8 to $9.4 \mathrm{~cm}$, while for schoolmasters mean FL varied from 4.5 to $13.5 \mathrm{~cm}$ (Table 1). There were significant differences in mean FL among stations (ANOVA: p < 0.001) and between years (ANOVA: $p<0.05$ ) for each species in each island.
Table 1. Mean (SE) fork lengths $(\mathrm{FL}, \mathrm{cm})$ of French grunt Haemulon flavolineatum and schoolmaster Lutjanus apodus by habitat, station, and year. Abbreviations for (1) St. Croix stations: AL, Altona Lagoon; SR, Salt River; TB, Teague Bay; TH, Turner Hole; GP, Great Pond. Station abbreviations for (2) Puerto Rico stations: CO, Corral; EL, El Palo; ML, Maria Langa; MO, Montalva; GU, Punta Guayanilla; (3) habitats: $\mathrm{MG}$, mangrove; $\mathrm{SG}$, seagrass

\begin{tabular}{|c|c|c|c|c|c|}
\hline Habitat & Station & $\begin{array}{c}\mathrm{N} \\
(2006)\end{array}$ & $\begin{array}{c}\text { FL } \\
(2006)\end{array}$ & $\begin{array}{c}\mathrm{N} \\
(2007)\end{array}$ & $\begin{array}{c}\text { FL } \\
(2007)\end{array}$ \\
\hline \multicolumn{6}{|c|}{ French grunt, St. Croix } \\
\hline MG & AL & 21 & $4.07(0.48)$ & 24 & $3.80(0.14)$ \\
\hline MG & SR & 24 & $5.48(0.36)$ & 24 & $9.40(0.15)$ \\
\hline $\mathrm{SG}$ & TB & 24 & $7.45(0.13)$ & 24 & $4.40(0.18)$ \\
\hline $\mathrm{SG}$ & $\mathrm{TH}$ & 24 & $8.29(0.15)$ & 24 & $6.97(0.18)$ \\
\hline \multicolumn{6}{|c|}{ French grunt, Puerto Rico } \\
\hline MG & MO & 24 & $5.80(0.39)$ & 24 & $5.16(0.31)$ \\
\hline MG & ML & 24 & $9.30(0.18)$ & 24 & $8.90(0.16)$ \\
\hline SG & $\mathrm{CO}$ & 24 & $7.80(0.10)$ & 24 & $7.40(0.31)$ \\
\hline SG & EL & 24 & $7.40(0.14)$ & 24 & $7.40(0.21)$ \\
\hline \multicolumn{6}{|c|}{ Schoolmaster, St. Croix } \\
\hline MG & AL & 21 & $9.60(0.35)$ & 24 & $5.20(0.30)$ \\
\hline MG & SR & 24 & $6.70(0.75)$ & 24 & $7.80(0.67)$ \\
\hline SG & TB & 24 & $9.60(0.49)$ & 24 & $10.60(0.78)$ \\
\hline SG & GP & 24 & $10.60(0.68)$ & 24 & $5.24(0.35)$ \\
\hline \multicolumn{6}{|c|}{ Schoolmaster, Puerto Rico } \\
\hline MG & $\mathrm{MO}$ & 24 & $7.15(0.61)$ & 24 & $7.30(0.70)$ \\
\hline MG & GU & 24 & $4.50(0.28)$ & 24 & $4.50(0.63)$ \\
\hline SG & $\mathrm{CO}$ & 20 & $11.30(0.30)$ & 20 & $13.50(0.80)$ \\
\hline SG & EL & 24 & $7.40(0.36)$ & 20 & $11.60(0.71)$ \\
\hline
\end{tabular}

\section{Individual elemental and stable isotope concentrations in French grunt}

In St. Croix, several of the element and stable isotopes examined ( $\left.\mathrm{Na}, \mathrm{Sr}, \mathrm{Mg},{ }^{13} \mathrm{C}\right)$ showed a significant relationship with the covariable otolith weight in the ANCOVA ( $p<0.05)$, which required the effect of the otolith weight to be removed for a subsequent ANOVA. For Puerto Rico, there were no significant relationships among elemental concentrations and stable isotopes with the covariable otolith weight in the ANCOVA ( $p>0.05)$.

The individual elemental concentrations and isotopic signatures of French grunts varied significantly among stations (ANOVA: p < 0.001) and years (ANOVA: p < $0.001)$ for St. Croix and Puerto Rico. There was also significant interaction among sites and years (ANOVA: $p<0.001$ ) for both islands. Since there were many significant interactions between year and station and year and habitat type (mangrove versus seagrass) for respective elements in 2-way ANOVA, 1-way ANOVA were employed to determine the spatial (among stations nested within habitats, and habitats within each year for each island for each species) and temporal (among years within each site or habitat for each spe- 
cies) variation of individual elemental and stable isotopes concentrations.

In St. Croix there were significant variations of $\mathrm{Sr}$, $\mathrm{Ba}, \mathrm{Na}, \mathrm{Co},{ }^{13} \mathrm{C}$ and ${ }^{18} \mathrm{O}$ among stations during both 2006 and 2007 (ANOVA: p < 0.001), while Cu showed significant variation among stations only in 2006 and Mg only in 2007 (ANOVA: p < 0.001) (Fig. 2). Both stable isotopes and all elements except $\mathrm{Cu}$ also showed significant within-station variability between years. For Puerto Rico, elemental concentrations of $\mathrm{Na}, \mathrm{Sr}$, $\mathrm{Ba}, \mathrm{Mg}, \mathrm{Co},{ }^{13} \mathrm{C}$ and ${ }^{18} \mathrm{O}$ varied significantly among stations in 2006, whereas in 2007 only $\mathrm{Sr}, \mathrm{Ba}, \mathrm{Cu}^{13} \mathrm{C}$ and ${ }^{18} \mathrm{O}$ varied among stations (ANOVA: $\mathrm{p}<0.001$ ) (Fig. 3). There was significant within-station variability between years for $\mathrm{Na}, \mathrm{Mg}$ and $\mathrm{Co}$ but not for the other metals or for either stable isotope. There was no appar-
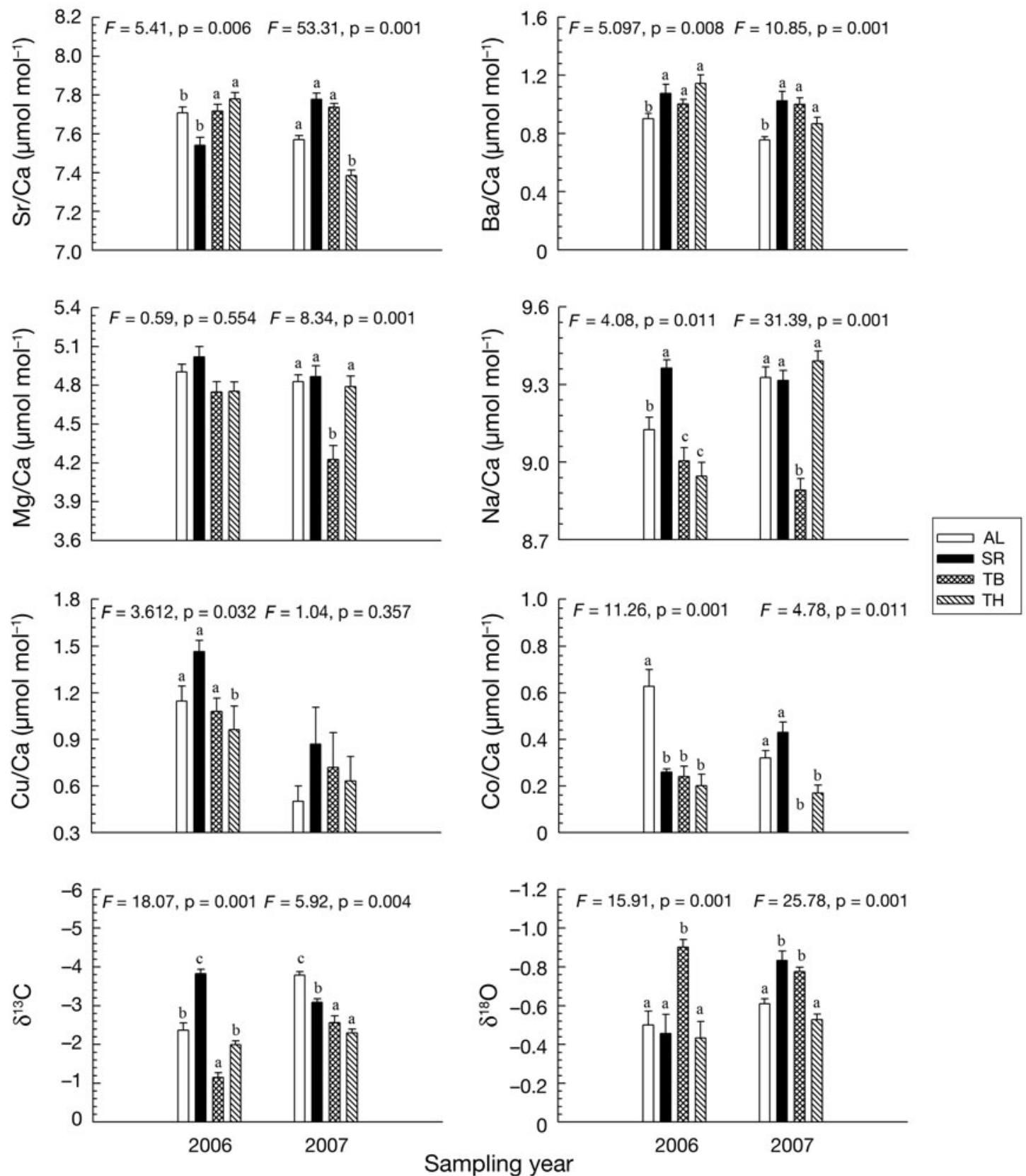

Fig. 2. Spatial and temporal variability in trace elements and stable isotopes measured in otoliths of young-of-the-year French grunts Haemulon flavolineatum collected in St. Croix in 2006 and 2007. Solid bars are mangrove stations and bars with patterns are seagrass stations. All trace element data (element/Ca $\left.\times 10^{3}\right)$ are $\ln (x+1)$ transformed. 1-way ANOVA on stations nested within habitats was used to detect differences within stations in each year. Stations indicated by different letters are significantly different from each other (Tukey's multicomparison test) 
ent trend in element concentrations among stations for both islands (Figs. 2 \& 3). Some elements that had a higher concentration at a given station in the first year were lower during the next, while in other cases the reverse was observed (Figs. $2 \& 3$ ). When stations were combined by habitat, $\mathrm{Sr}$ and ${ }^{13} \mathrm{C}$ were significantly higher in seagrass habitats in St. Croix, whereas $\mathrm{Na}$, $\mathrm{Mg}$, Co and ${ }^{18} \mathrm{O}$ were higher in mangrove habitats
(ANOVA: $\mathrm{p}<0.001$ ). In Puerto Rico, $\mathrm{Sr},{ }^{13} \mathrm{C}$ and ${ }^{18} \mathrm{O}$ concentrations were significantly higher in seagrass habitats (ANOVA: $\mathrm{p}<0.001$ ) while $\mathrm{Co}$ and $\mathrm{Cu}$ were significantly higher in mangrove habitats (ANOVA: $p$ $<0.001$ ). Only $\mathrm{Na}$ and ${ }^{18} \mathrm{O}$ varied across years when stations were combined by habitat for St. Croix (ANOVA: $\mathrm{p}<0.001$ ), while for Puerto Rico only Mg and Co varied (ANOVA: $\mathrm{p}<0.001$ ).
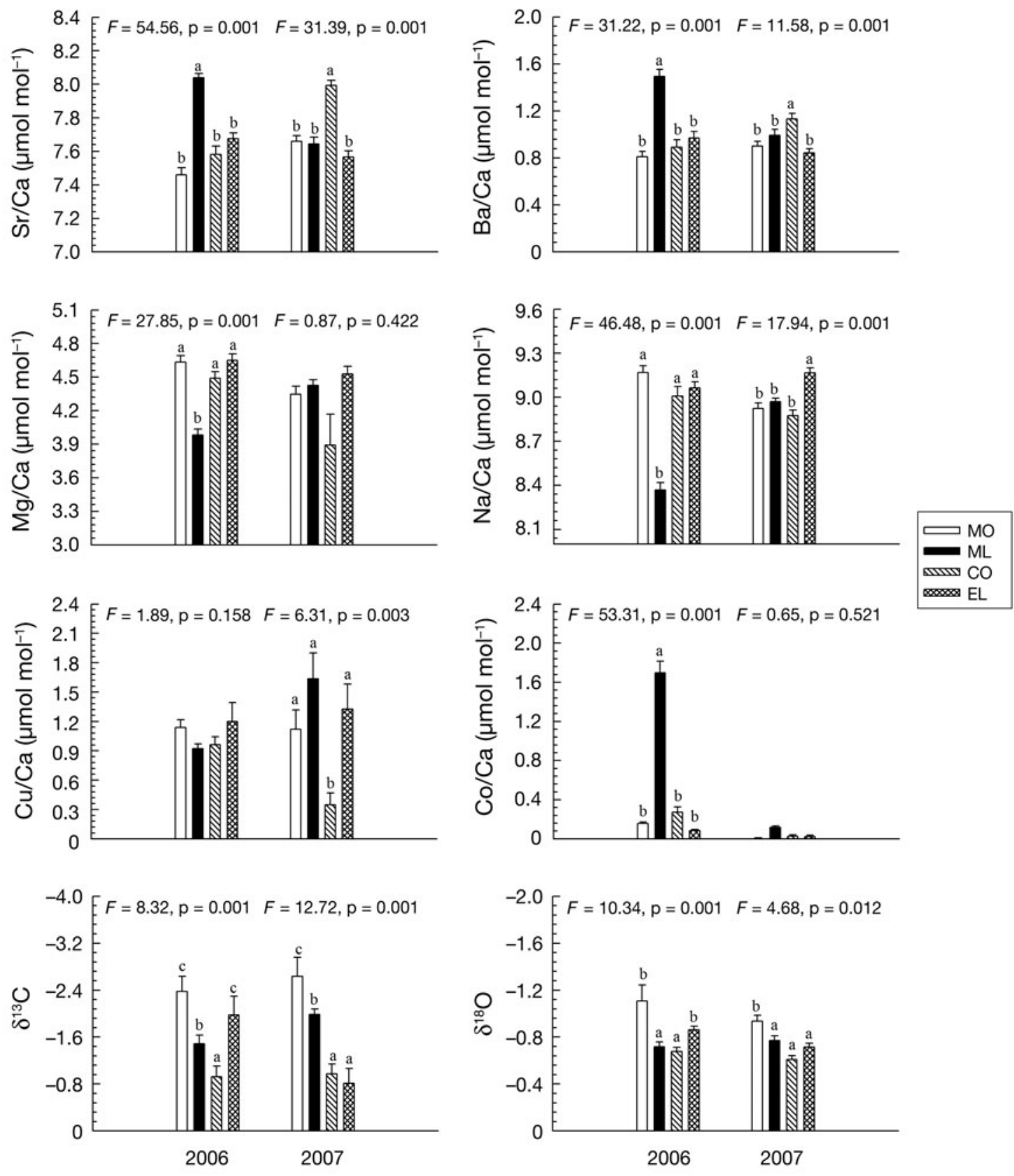

\section{Sampling year}

Fig. 3. Spatial and temporal variability in trace elements and stable isotopes measured in otoliths of young-of-the-year Frenchgrunts Haemulon flavolineatum collected in Puerto Rico in 2006 and 2007. For details see legend of Fig. 2 (Tukey's multicomparison test) 


\section{Individual elemental concentrations in schoolmaster}

In St. Croix, of all trace elements examined, only Ba showed a significant relationship with the covariable otolith weight in the ANCOVA, requiring the effect of the covariable to be removed for both islands (ANCOVA: $p$ < 0.001). In St. Croix and Puerto Rico, the elemental concentrations and isotopic signatures of schoolmaster varied significantly among stations
(ANOVA: $\mathrm{p}<0.001$ ) and years (ANOVA: $\mathrm{p}<0.001$ ). There was also significant interaction among stations and year (ANOVA: $p<0.001$ ). There were significant variations among stations for $\mathrm{Na}, \mathrm{Sr}, \mathrm{Ba}, \mathrm{Mg}$, Co and ${ }^{13} \mathrm{C}$ during 2006 in St. Croix, and $\mathrm{Ba}, \mathrm{Co},{ }^{13} \mathrm{C}$ and ${ }^{18} \mathrm{O}$ in Puerto Rico (ANOVA: p < 0.001; Tukey's HSD test: $\mathrm{p}<$ 0.05) (Figs. 4 \& 5, respectively). During 2007, $\mathrm{Na}, \mathrm{Sr}$, $\mathrm{Cu}, \mathrm{Co},{ }^{13} \mathrm{C}$ and ${ }^{18} \mathrm{O}$ varied among stations in St. Croix (Fig. 4), and $\mathrm{Sr}, \mathrm{Ba}, \mathrm{Mg}, \mathrm{Cu},{ }^{13} \mathrm{C}$ and ${ }^{18} \mathrm{O}$ varied among
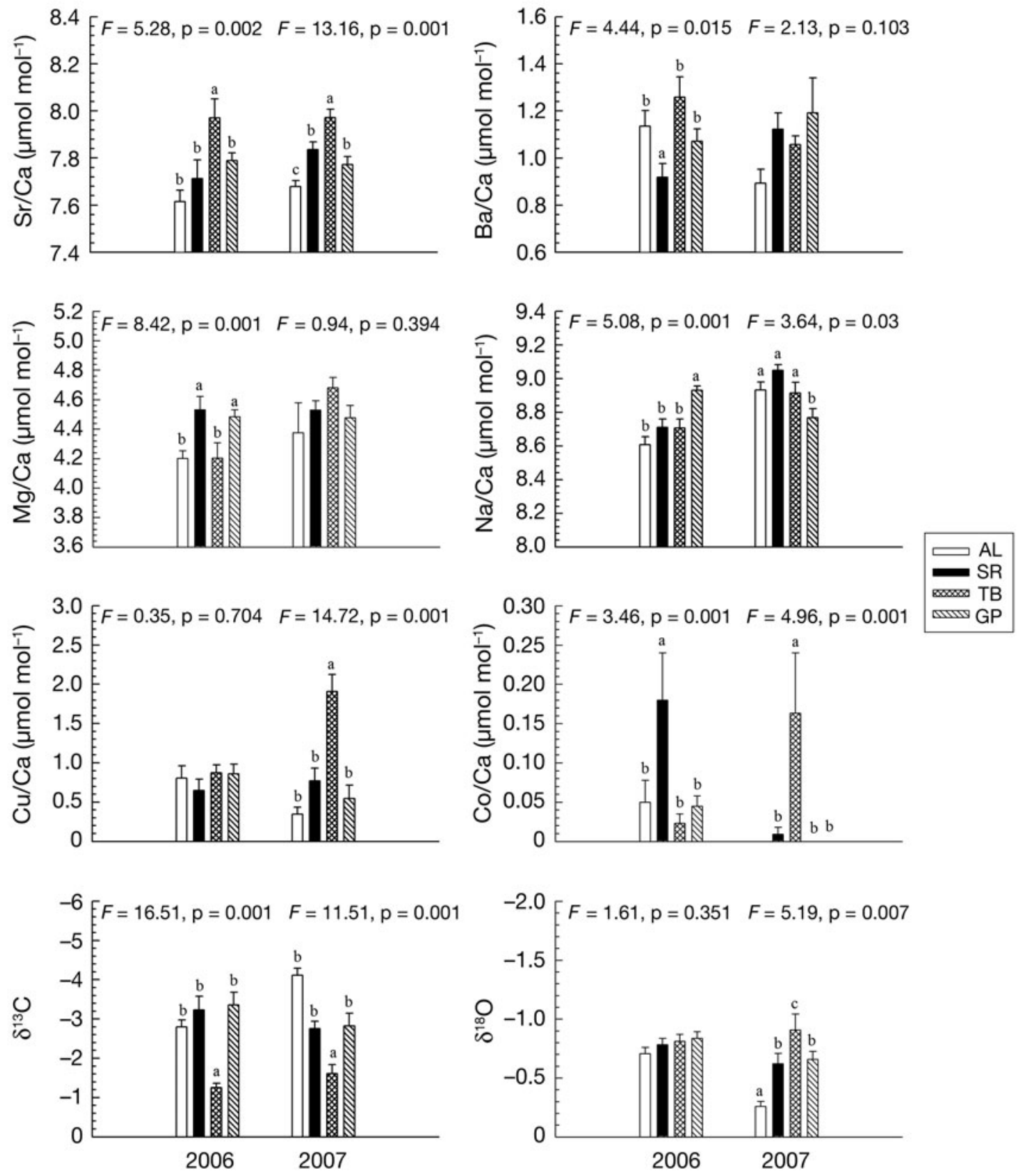

Sampling year

Fig. 4. Spatial and temporal variability in trace elements and stable isotopes measured in otoliths of young-of-the-year schoolmasters Lutjanus apodus collected in St. Croix in 2006 and 2007. For details see legend of Fig. 2 (Tukey's multicomparison test) 
Puerto Rico stations in 2007 (ANOVA: p < 0.001) (Fig. 5). There was within-station variability between years for $\mathrm{Na}$ and ${ }^{18} \mathrm{O}$ in St. Croix, and for $\mathrm{Sr}, \mathrm{Ba}$ and $\mathrm{Co}$ in Puerto Rico (ANOVA: p < 0.001). No trends in element concentrations among stations were apparent for St. Croix. Isotopic signatures within stations for Puerto Rico did not significantly vary temporally. Some elements that were higher at a given station the first year were lower the next year and vice versa. When stations were combined by habitat only $\mathrm{Na}$ and ${ }^{18} \mathrm{O}$ elemental concentrations varied across years for St. Croix (ANOVA: $\mathrm{p}<0.001$ ), and only $\mathrm{Ba}$ and Co varied for Puerto Rico (ANOVA: $\mathrm{p}<0.001$ ). In St. Croix, Sr, Cu and ${ }^{13} \mathrm{C}$ were significantly higher in seagrass habitats (ANOVA: $\mathrm{p}<0.001$ ), whereas ${ }^{18} \mathrm{O}$ was higher in mangrove habitats (ANOVA: $\mathrm{p}<0.001$ ). In Puerto Rico, Sr, $\mathrm{Ba}$ and ${ }^{13} \mathrm{C}$ were significantly higher in seagrass habitats (ANOVA: $\mathrm{p}<0.001$ ) while $\mathrm{Mg}$ and ${ }^{18} \mathrm{O}$ concentrations were higher in mangrove habitats (ANOVA: $\mathrm{p}<0.001)$.
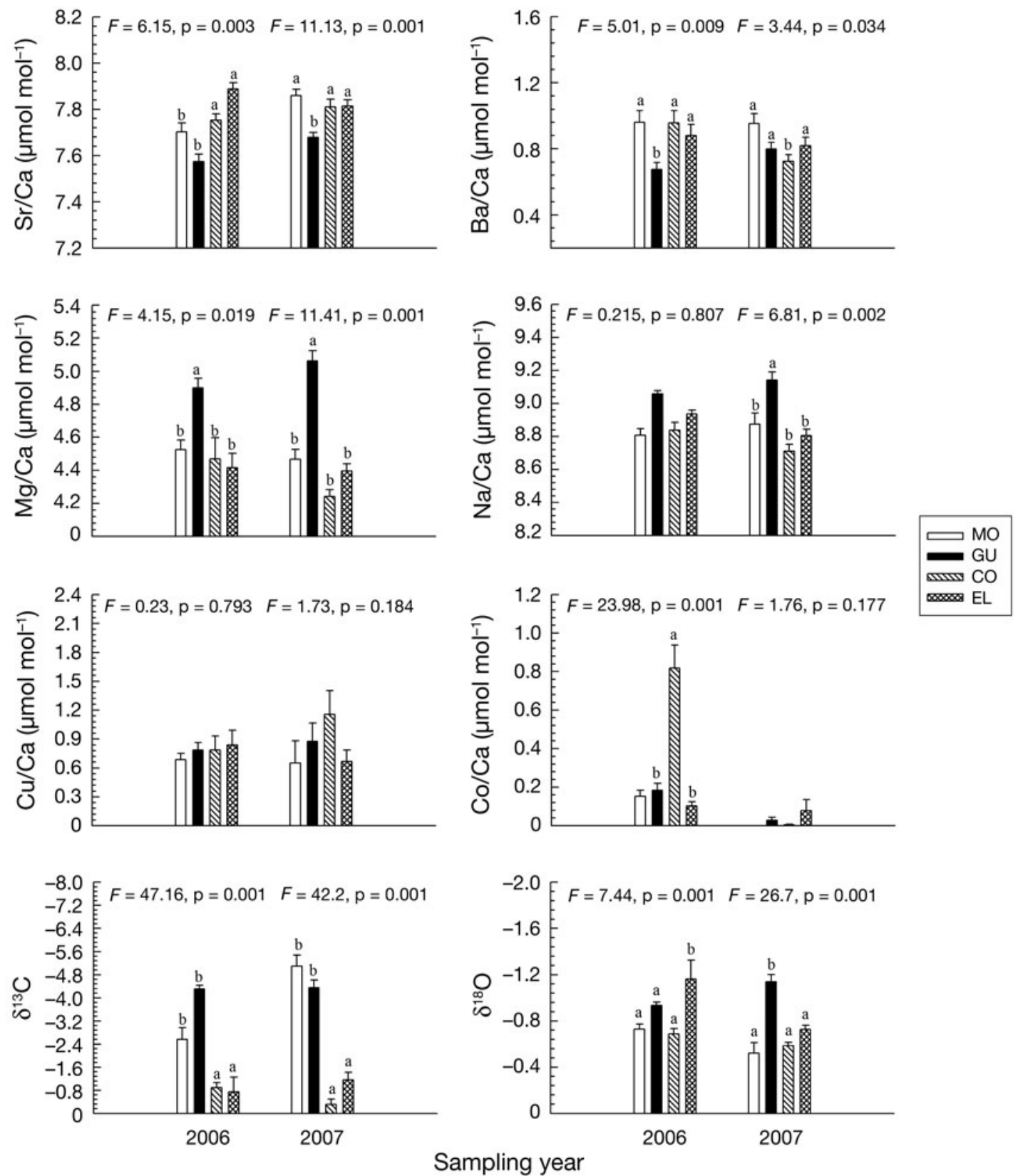

Fig. 5. Spatial and temporal variability in trace elements and stable isotopes measured in otoliths of young-of-the-year schoolmasters Lutjanus apodus collected in Puerto Rico in 2006 and 2007. For details see legend of Fig. 2 (Tukey's multicomparison test) 


\section{Multi-elemental and stable isotope concentrations}

Results of MANOVA showed that multi-elemental and stable isotope signatures of both juvenile French grunt and schoolmaster otoliths differed significantly among stations in each island (MANOVA: St. Croix French grunt, p < 0.001; St. Croix schoolmaster, $\mathrm{p}<0.001$; Puerto Rico French grunt, $p<0.001$; Puerto Rico schoolmaster, $\mathrm{p}<0.001$ ), and between years (MANOVA: St. Croix French grunt, $\mathrm{p}<0.001$; St. Croix schoolmaster, $\mathrm{p}<0.001$; Puerto Rico French grunt, $\mathrm{p}<0.001$; Puerto Rico schoolmaster, $\mathrm{p}<0.001$ ) for St. Croix and Puerto Rico. There was also a significant interaction between station and year (MANOVA: St. Croix French grunt, p < 0.001 ; St. Croix schoolmaster, $\mathrm{p}<0.001$; Puerto Rico French grunt, p $<0.001$; Puerto Rico schoolmaster, $\mathrm{p}<0.001$ ), implying that the multi-elemental signatures differed among years depending on the station studied. Signatures also differed significantly between habitats (MANOVA: St. Croix French grunt, $\mathrm{p}<$ 0.001; St. Croix schoolmaster, $\mathrm{p}<0.001$; Puerto Rico French grunt, p $<0.001$; Puerto Rico schoolmaster, $\mathrm{p}<0.001)$. Significant interactions also existed between year and habitat (MANOVA: St. Croix French grunt, $\mathrm{p}<0.001$; St. Croix schoolmaster, $\mathrm{p}<0.001$; Puerto Rico French grunt, $\mathrm{p}<$ 0.001; Puerto Rico schoolmaster, $\mathrm{p}<0.001)$.

The average classification success for St. Croix French grunt nursery stations using both trace elements and stable isotopes was $87 \%$ for 2006 and $92 \%$ for 2007, while for Puerto Rico it was $84 \%$ in 2006 and $80 \%$ in 2007 (Table 2). When stations were combined by habitat, classification success between mangrove and seagrass habitats was $96 \%$ in St. Croix during both years, and 91 to $84 \%$ during 2006 and 2007, respectively, in Puerto Rico (Table 3). Elements that were important in the discrimination of French grunt nursery stations and habitats in Puerto Rico were $\mathrm{Na}$, $\mathrm{Co}, \mathrm{Sr}, \mathrm{Ba},{ }^{13} \mathrm{C}$ and ${ }^{18} \mathrm{O}$, and for St. Croix were $\mathrm{Na}, \mathrm{Sr}$, ${ }^{13} \mathrm{C}$ and ${ }^{18} \mathrm{O}$. For schoolmaster average classification success within the 4 St. Croix nurseries was $77 \%$ in 2006 and $76 \%$ in 2007, while in Puerto Rico it was $87 \%$ in 2006 and $84 \%$ in 2007 (Table 3). When data were combined by habitat, the results of the cross-validation procedure showed that the classification accuracy of the otoliths from the 2 habitats was $89 \%$ during 2006 and $86 \%$ during 2007 in St. Croix, and 94 and 99\% during 2006 and 2007, respectively, in Puerto Rico (Table 3). Elements that were important in the discrimination of schoolmaster nursery stations and habitats in Puerto Rico were $\mathrm{Na}, \mathrm{Mg}, \mathrm{Co}, \mathrm{Sr}, \mathrm{Ba},{ }^{13} \mathrm{C}$ and ${ }^{18} \mathrm{O}$, and for St. Croix were $\mathrm{Na}, \mathrm{Cu}, \mathrm{Sr},{ }^{13} \mathrm{C}$ and ${ }^{18} \mathrm{O}$.

\section{Subadult connectivity}

The results from the maximum likelihood analysis, using trace metal and stable isotope data of postsettlement regions of juvenile schoolmasters collected in 2006 and 2007 as the reference database, showed that $99 \%$ of the subadult schoolmasters collected in 2007 and 2008 came from mangrove nursery habitats in both islands (Table 4). A similar analysis showed that French grunt subadults originated from both habitats, with $70 \%$ coming from mangrove and $30 \%$ from seagrass in Puerto Rico in 2007, and $74 \%$ coming from mangrove and $26 \%$ from seagrass in 2008. In St. Croix, 
Table 3. Jackknifed classification success using quadratic discriminant function analysis for schoolmaster Lutjanus apodus otoliths collected in St. Croix and Puerto Rico. Abbreviations defind in Table 1

\begin{tabular}{|c|c|c|c|c|c|c|c|c|c|}
\hline Stations & $\mathrm{AL}$ & GP & $\mathrm{SR}$ & TB & $\begin{array}{c}\% \\
\text { Correct }\end{array}$ & Habitat & $\mathrm{MG}$ & $\mathrm{SG}$ & $\begin{array}{c}\% \\
\text { Correct }\end{array}$ \\
\hline \multicolumn{10}{|c|}{ St. Croix, 2006} \\
\hline $\mathrm{AL}$ & 16 & 0 & 3 & 2 & 76 & MG & 34 & 7 & 83 \\
\hline GP & 2 & 14 & 1 & 1 & 78 & $\mathrm{SG}$ & 2 & 36 & 95 \\
\hline SR & 3 & 0 & 15 & 2 & 75 & Total & 36 & 43 & 89 \\
\hline TB & 1 & 1 & 2 & 16 & 80 & & & & \\
\hline Total & 22 & 15 & 21 & 21 & 77 & & & & \\
\hline \multicolumn{10}{|c|}{ St. Croix, 2007} \\
\hline $\mathrm{AL}$ & 21 & 0 & 2 & 0 & 91 & MG & 41 & 5 & 89 \\
\hline GP & 3 & 11 & 4 & 2 & 55 & SG & 7 & 31 & 82 \\
\hline SR & 2 & 3 & 17 & 1 & 74 & Total & 48 & 36 & 86 \\
\hline TB & 0 & 1 & 2 & 15 & 83 & & & & \\
\hline Total & 26 & 15 & 25 & 18 & 76 & & & & \\
\hline Stations & $\mathrm{CO}$ & EL & GU & $\mathrm{MO}$ & $\begin{array}{c}\% \\
\text { Correct }\end{array}$ & Habitat & $\mathrm{MG}$ & $\mathrm{SG}$ & $\begin{array}{c}\% \\
\text { Correct }\end{array}$ \\
\hline \multicolumn{10}{|c|}{ Puerto Rico, 2006} \\
\hline $\mathrm{CO}$ & 18 & 0 & 0 & 2 & 90 & MG & 34 & 4 & 89 \\
\hline EL & 1 & 19 & 0 & 0 & 95 & $\mathrm{SG}$ & 1 & 39 & 98 \\
\hline GU & 0 & 0 & 17 & 4 & 81 & Total & 35 & 43 & 94 \\
\hline $\mathrm{MO}$ & 2 & 0 & 1 & 14 & 82 & & & & \\
\hline Total & 21 & 19 & 18 & 20 & 87 & & & & \\
\hline \multicolumn{10}{|c|}{ Puerto Rico, 2007} \\
\hline $\mathrm{CO}$ & 13 & 6 & 0 & 1 & 65 & MG & 39 & 0 & 100 \\
\hline EL & 3 & 18 & 0 & 0 & 90 & SG & 1 & 39 & 98 \\
\hline GU & 0 & 1 & 19 & 0 & 95 & Total & 40 & 39 & 99 \\
\hline $\mathrm{MO}$ & 0 & 1 & 2 & 17 & 85 & & & & \\
\hline Total & 16 & 26 & 21 & 18 & 84 & & & & \\
\hline
\end{tabular}

$40 \%$ of French grunt subadults originated from mangrove and $60 \%$ from seagrass habitats in 2007, and in 2008, $68 \%$ of French grunt subadults originated from mangrove and $32 \%$ from seagrass habitats. When we scaled up the results from our study by using areas of each habitat type, in Puerto Rico the contribution of subadults per area of Montalva and Corral to adult French grunt populations in Turrumote was 0.2 individuals (ind.) $\mathrm{km}^{-2}$, for both seagrass and mangrove habitats, respectively, across years (Table 4). For schoolmaster, the contribution to adult populations in Turrumote was 0.27 and 0.07 ind. $\mathrm{km}^{-2}$ for mangrove and seagrass habitats, respectively, across years (Table 4). In St. Croix, the contributions per area of Salt River to adult French grunt populations of adjacent reefs were 2.86 and 3.3 ind. $\mathrm{km}^{-2}$ for seagrass and mangrove habitats, respectively, in 2007, and 1.52 and 5.67 ind. $\mathrm{km}^{-2}$ in 2008, respectively. For schoolmaster, the contribution per area of Salt River to adjacent reefs was 0.05 and 8.2 ind. $\mathrm{km}^{-2}$ for seagrass and mangrove habitats, respectively, across years.

\section{DISCUSSION}

Many studies in the Caribbean have observed juveniles of coral reef fishes in mangroves and in seagrass beds (e.g. Nagelkerken et al. 2000a,b,c, Mumby et al. 2004). The adults of these species have also been observed on the coral reef or in offshore waters, suggesting that the juveniles migrate from the mangroves and seagrass beds to the reef or deeper waters at a certain age (Appeldoorn et al. 1997, Nagelkerken et al. 2000a,b,c, Cocheret de la Morinière et al. 2002). These results suggest seagrass meadows and mangrove lagoons have a critical role as nurseries for adult fish populations of reefs. However, there is little direct evidence of the functioning of these habitats as nursery areas and whether the higher juvenile biomass in these habitats is successfully transferred to the adult populations (Beck et al. 2001, Gillanders 2005). Establishing this link between juvenile and adult populations is critical for distinguishing between habitats that are productive for resident individuals and habitats that are actually serving as nurseries (i.e. supplying large numbers of individuals to adult habitats). There have been several approaches to study connectivity among mangrove habitats such as the use of tagging (Appeldoorn et al. 1997, Luo et al. 2009), mathematical algorithms (Mumby et al. 2004), ontogenetic change in size and feeding habits (Nagelkerken et al. 2000a,b,c, Cocheret de la Morinière et al. 2003, Nakamura et al. 2008). However, these attempts do not answer the question of how many fish are being recruited to the adult populations.

This study provides the first direct and robust evidence of post-settlement fish movement connecting tropical mangrove habitats to the coral reef using otolith chemistry and estimates of the contribution of local mangrove fish production per area to offshore populations. Our study found that distinct natural tags existed among seagrass and mangrove habitats that were used to successfully discriminate juvenile fish from different areas. Application of these natural tags to subadults revealed that mangrove nursery habitats contributed disproportionately high numbers to subadult recruitment compared with seagrass habitats for schoolmaster across both islands, whereas habitat specific contributions were more similar for French 
Table 4. Estimates of proportion and contribution per area of French grunt Haemulon flavolineatum and schoolmaster Lutjanus apodus subadults originating from mangrove and seagrass habitatsfor 2007 and 2008. Estimates are based on data from $\mathrm{Sr}, \mathrm{Ba}, \mathrm{Mg}, \mathrm{Cu}, \mathrm{Na}^{13} \mathrm{C}$ and ${ }^{18} \mathrm{O}$ in the postsettlement portion of the otoliths of subadults captured in 2007 and 2008 and using the data from juveniles captured in 2006 and 2007 as reference data sets. N: number of subadult samples

\begin{tabular}{|lccccc|}
\hline \multicolumn{2}{c}{$\begin{array}{c}\text { French } \\
\text { grunt }\end{array}$} & $\begin{array}{c}\text { School- } \\
\text { master }\end{array}$ & $\begin{array}{c}\text { Area } \\
\left(\mathrm{km}^{2}\right)\end{array}$ & $\begin{array}{c}\text { Contribution km } \\
\text { French } \\
\text { grunt }\end{array}$ & $\begin{array}{c}\text { School- } \\
\text { master }\end{array}$ \\
\hline $\mathbf{2 0 0 7}$ & & & & & \\
St. Croix: Salt River & & & & & \\
Seagrass & 0.6 & 0.01 & 0.21 & 2.86 & 0.05 \\
Mangrove & 0.4 & 0.99 & 0.12 & 3.33 & 8.25 \\
N & 24 & 21 & & & \\
Puerto Rico: Turrmote, La Parguera & & & & \\
Seagrass (Corral) & 0.3 & 0.1 & 1.50 & 0.20 & 0.07 \\
Mangrove (Montalva) & 0.7 & 0.99 & 3.70 & 0.19 & 0.27 \\
N & 24 & 24 & & & \\
2008 & & & & & \\
St. Croix: Salt River & & & & & \\
Seagrass & 0.32 & 0.01 & 0.21 & 1.52 & 0.05 \\
Mangrove & 0.68 & 0.99 & 0.12 & 5.66 & 8.25 \\
N & 24 & 21 & & & \\
Puerto Rico: Turrumote, La Parguera & & & & \\
Seagrass (Corral) & 0.26 & 0.01 & 1.50 & 0.20 & 0.07 \\
Mangrove (Montalva) & 0.74 & 0.99 & 3.70 & 0.20 & 0.27 \\
N & 24 & 24 & & & \\
\hline
\end{tabular}

grunt. The percentage of the French grunt subadults identified as having resided as juveniles in mangrove habitats the previous year was estimated to range between 40 and $68 \%$ for Salt River, St. Croix, and between 70 and $74 \%$ for La Parguera, Puerto Rico. For schoolmaster almost $100 \%$ of all fish resided in mangrove habitats in both islands across years. These results suggest that mangrove habitats in these regions may be acting as 'nursery habitats' by contributing more individuals per unit area to schoolmaster adult populations than the adjacent seagrass habitats, whereas for French grunt mangrove and seagrass may be contributing in similar proportions to the adult populations in the local regions studied in St. Croix and Puerto Rico.

Reasons why mangrove habitats appear to contribute more to adult populations of one species than the to the other are unclear (Cocheret de la Morinière et al. 2003, Pollux et al. 2007). Among possible explanations are different habitat settlement preferences and migration life cycles of the 2 species. Fish settlement studies have found that schoolmaster larvae tend to settle primarily into the mangrove habitats while French grunt settle in several habitats (Pollux et al. 2007). As a result few schoolmaster juveniles are found in seagrass habitats. Furthermore, Cocheret de la Morinière et al. (2003) found that schoolmasters settle, grow and develop to a later stage in mangrove habitats before they move to reef habitats and termed this period as long postsettlement life cycle migration. For French grunts, Cocheret de la Morinière et al. (2003) defined their migration as a stepwise postsettlement life cycle where, in contrast to schoolmasters, French grunt juveniles dwell in shallow water mangrove and seagrass habitats close to the backreef. Larger individuals then move to deeper habitats where they grow to subadult size, at which point they migrate to nearby forereef habitats.

Another reason for the disproportionate contribution of mangrove juvenile habitat to the adult populations compared with seagrass habitat may be due to fish in that habitat having higher densities, higher growth rates, lower mortality or more successful recruitment to the adult population (Beck et al. 2001). In the Caribbean, densities of both schoolmasters and French grunts are greater in mangrove habitat (Nagelkerken et al. 2000a,b,c, Cocheret de la Morinière et al. 2002, Mumby et al. 2004, Aguilar-Perera \& Appeldoorn 2007). Using otolith microstructure of the same fish as used in the present study, Mateo (2009) found higher growth rates in mangrove than in seagrass habitats for schoolmasters and French grunts during the postsettlement period in Puerto Rico and St. Croix. These findings suggest that mangrove habitats may be producing more juvenile schoolmasters and French grunts because they support faster growing fish that successfully recruit to the adult population.

A possible source of error in the classification models by station is that misclassified fish had recently moved into the collection habitat from the adjacent alternative habitat type (Chittaro et al. 2005, 2006). One of the assumptions in otolith chemistry studies is that captured fish must have resided close to their collection sites for sufficiently long to reflect local conditions (Brown 2006, Fodrie \& Herzka 2008). This may be a reasonable assumption if collection stations are separated by 10 to $100 \mathrm{~km}$. However, this may not be the case for nearby collection stations if there is shortterm, small-scale movement of fish. Movement of individuals between mangrove and nonmangrove coastal habitats before capture would result in a chemical tag that was either typical of the alternative habitat type or an intermediate value depending on the timing of the movement. By examining the period of recent growth in the otolith edge and comparing the elemental con- 
centrations in the otoliths of French grunts inhabiting the backreef with those captured on the backreef and transported to a enclosed environment in mangroves in Belize for a period of $2 \mathrm{wk}$, Chittaro et al. (2004) found differences in elemental fingerprints in the otolith edge between fish captured from the backreef and fish transported to the enclosure area and suggested that fish from these 2 habitats could be discriminated on the basis of otolith elemental concentrations. However, in a follow-up study, they subsequently found low discrimination among juvenile French grunts and schoolmasters captured in mangrove and back-reef nursery grounds based on otolith chemistry Chittaro et al. (2005, 2006). Within-station discrimination success in their study was about $46 \%$ for French grunt and $40 \%$ for schoolmaster, and $75 \%$ and $67 \%$ for habitat, respectively, which was considerably less than what we found either within each species per station by island $(85 \%)$ and within each species within habitats $(92 \%)$. Chittaro et al. $(2005,2006)$ concluded that some individuals collected from mangrove habitats in their study might have recently moved into the backreef during their night-feeding migration. The discriminant model would have misclassified these individuals because their otoliths would contain a 'nonmangrove' habitat tag. Error in classification of fish in the reef may have been caused by the reverse phenomenon: fish collected on the backreef might have a mangrove signature because they might have recently moved to mangrove areas during their night-feeding migration. Our better discrimination overall probably reflects the fact that we used the stable isotopes ${ }^{13} \mathrm{C}$ and ${ }^{18} \mathrm{O}$ in addition to trace metals alone as used by Chittaro et al. $(2005,2006)$, as well as the fact that we used the otolith region of the postsettlement period.

Fish otoliths from most of the mangrove stations were characterized by consistently lower levels of ${ }^{13} \mathrm{C}$ whereas fish from seagrass had otoliths that were enriched with ${ }^{13} \mathrm{C}$. This is expected since stable isotope carbon values in mangroves are significantly depleted compared with those from seagrass beds (Cocheret de la Morinière et al. 2003, Kieckebusch et al. 2004, Nagelkerken \& van der Velde 2004). These differences are reflected in soft tissues of organisms inhabiting these habitats (Cocheret de la Morinière et al. 2003, Kieckebusch et al. 2004, Nakamura et al. 2008). Studies using stable isotopes in hard parts such as otoliths in tropical reef fish have been fewer than those using stable isotopes in soft tissues (Dufour et al. 1998, Huxham et al. 2007, Verweij et al. 2008). However, the use of hard parts has the advantage over tissue analysis in that the signature is fixed at the time the material is laid down in the otolith and do not change rapidly depending on diet. The utility of using stable isotopes in otoliths to discriminate between habitats was demon- strated by Huxham et al. (2007), who used ${ }^{13} \mathrm{C}$ in otoliths as a marker for fish between mangrove and offshore populations in Gazi Bay, Kenya. Otoliths of fish from mangroves had depleted values of ${ }^{13} \mathrm{C}$ while those from offshore were enriched. Similarly, Verweij et al. (2008) showed evidence of connectivity and movement between seagrass and offshore reefs for yellowtail snapper Ocyurus chrysurus in Curacao. Based on comparisons of isotopic signatures of ${ }^{13} \mathrm{C}$ on the edge zone of the otoliths in juvenile yellowtail snapper caught in seagrass and adults from the outer reef, they found that ${ }^{13} \mathrm{C}$ in otoliths of juveniles was more enriched than in those of adults found at the outer reef.

Differences in ontogeny (Thresher et al. 1994, Proctor et al. 1995), physiology (Kalish 1989), growth rates (Sadovy \& Severin 1992, 1994, Thresher et al. 1994) and diet (Sanchez-Jerez et al. 2002, Buckel et al. 2004) are potential factors influencing differences in otolith elemental composition in fish. Thus, effects of physiology and ontogeny should be substantially minimized by examining fish of the same age and similar size. As previously mentioned, Chittaro et al. $(2005,2006)$ had difficulties in interpreting chemical signatures of juvenile schoolmasters and French grunts because they examined the edge (period of recent growth) on fish of different sizes. Another associated problem is that their night-feeding migrations to several habitats (reef to mangrove, mangrove to reef) may mask any particular habitat signature.

To avoid this problem we decided to examine the otolith region of the postsettlement period. At this early life stage, both fish species would have a size about 2 to $3 \mathrm{~cm}$ FL (Lindeman 1997). The size range of the French grunts captured in Belize was 7 to $14 \mathrm{~cm}$ (Chittaro et al. 2005), while the average size of schoolmasters was $17.6 \mathrm{~cm}$ (Chittaro et al. 2006). By measuring chemical composition of the otoliths at the same time in the development of each species we reduced possible effects of factors such as growth and movement that might mask results in elemental fingerprints. Further, by determining a chemical signature in the otoliths during an early life stage, the discriminatory power of otolith analysis would increase as these small fish may move relatively short distances within habitats $(<100 \mathrm{~m})$ resulting in a characteristic representation of the habitat in which they spend their postsettlement period. Recent evidence from tagging studies in Curacao of small-scale movements for schoolmasters and French grunts of approximately $15 \mathrm{~cm}$ FL in size showed that their mean linear distances during the day were <75 m (Verweij \& Nagelkerken 2007, Verweij et al. 2007). Therefore, we believe that these natural tags corresponded to the early life history period of these species in which juvenile dispersal among juvenile areas and habitats was probably limited. 


\section{CONCLUSIONS}

We have demonstrated that juvenile schoolmasters and French grunts from different nursery areas can be distinguished based on their otolith chemistry with a high classification success. Although more information on the spatial and temporal variation in water chemistry and the relationship between ambient water and otolith chemistry is needed to fully interpret otolith geochemical signatures, the data presented indicate that otolith chemistry holds promise in studies of fish movement along shore and connectivity among shallow water nursery grounds and adult habitats for reef fish species. Our study contains the first direct and robust evidence of postsettlement fish movement connecting tropical mangrove habitats to the coral reef using natural tags. Almost all schoolmasters and many French grunts spent a certain part of their juvenile phase in mangrove nurseries. This means that for both species' conservation, protecting only coral reef habitats will not be enough. Worldwide, marine protected areas (MPAs) most often include single habitat types such as coral reefs. MPAs should include all ecologically linked nearshore habitats, such as seagrass beds and mangroves.

Acknowledgements. We thank H. Rivera and W. Tobias from USVI Division Fish and Wildlife, St. Croix, fishermen J. Sanchez and G. Martinez, and St. Croix Anchor Dive for their help and support in St. Croix. Special thanks go to $\mathrm{M}$. Nemeth, T. Marziak, H. Ruiz, M. Rosado and G. Martinez from the University of Puerto Rico, and to P. Collazo for support and assistance in Puerto Rico. We also thank Dr. K. Kelley for her assistance with the trace metal analysis at the ICPMS lab at the Graduate School of Oceanography, University of Rhode Island, and Dr. K. Friedland for his assistance at the image analysis lab at NOAA Northeast Fisheries Science Center at Narragansett, Rhode Island. We also thank Dr. C. Weidman for assistance in the use of the micromilling machine at WHOI. Special thanks go to Drs. J. Hare, G. Forrester, D. Bengtson, C. Recksiek, P. Chittaro and J. Rooker for their critical reviews and comments on previous versions of the manuscript. This study was funded through Puerto Rico Sea Grant Program (Grant No. AN05-05-030), PADI Aware Foundation, and Sigma Xi.

\section{LITERATURE CITED}

Adams A, Ebersole J (2002) Use of back-reef and lagoon habitats by coral reef fishes. Mar Ecol Prog Ser 228:213-226

Aguilar-Perera A, Appeldoorn RS (2007) Variation in juvenile fish density along the mangrove-seagrass-coral reef continuum in SW Puerto Rico. Mar Ecol Prog Ser 348:139-148

Appeldoorn RS, Recksieck CW, Hill RL, Pagan FE, Dennis GD (1997) Marine protected areas and reef fish movements: the role of habitat in controlling ontogenetic movements. Proc 8th Int Coral Reef Symp, Panama City 2:1917-1922

Beck MW, Heck KL Jr, Able KW, Childers DL and others (2001) The identification, conservation, and management of estuarine and marine nurseries for fish and invertebrates. BioScience 51:633-641

Billings VC, Munro JL (1974) The biology, ecology, exploitation and management of Caribbean reef fishes: Pomadasydae (grunts). Part 5 Res Rep Zool Dep Univ West Indies 3:1-128

Brothers EB, McFarland WN (1981) Correlations between otolith microstructure, growth and life history transitions in newly recruited French grunts Haemulon flavolineatum [(Desmarest), Haemulidae]. Rapp P-V Réun Cons Int Explor Mer 178:369-374

Brown JA (2006) Using the chemical composition of otoliths to evaluate the nursery role of estuaries for English sole Pleuronectes vetulus populations. Mar Ecol Prog Ser 306: 269-281

Buckel JA, Sharack BL, Zdanowicz VS (2004) Effect of diet on otolith composition in Pomatomus saltatrix, an estuarine piscivore. J Fish Biol 64:1469-1484

> Campana SE (1999) Chemistry and composition of fish otoliths: pathways, mechanisms and applications. Mar Ecol Prog Ser 188:263-297

Campana SE, Chouinard GA, Hanson JM, Frechet A, Brattey $\mathrm{J}$ (2000) Otolith elemental fingerprints as biological tracers of fish stocks. Fish Res 46:343-357

Chittaro PM, Fryer BJ, Sale PF (2004) Discrimination of French grunts (Haemulon flavolineatum, Desmarest, 1823) from mangrove and coral reef habitats using otolith microchemistry. J Exp Mar Biol Ecol 308:169-183

Chittaro PM, Usseglio P, Fryer BJ, Sale PF (2005) Using otolith microchemistry of Haemulon flavolineatum (French grunt) to characterize mangroves and coral reefs throughout Turneffe Atoll, Belize: difficulties at small spatial scales. Estuaries 28:373-381

Chittaro PM, Usseglio P, Fryer BJ, Sale PF (2006) Spatial variation in otolith chemistry of Lutjanus apodus at Turneffe Atoll, Belize. Estuar Coast Shelf Sci 67:673-680

Claro R, García-Arteaga JP (1994) Crecimiento. In: Claro R (ed) Ecología de los peces marinos de Cuba. Instituto de Oceanología Academia de Ciencias de Cuba and Centro de Investigaciones de Quintana Roo (CIQRO), p 321-402

Cocheret de la Morinière E, Pollux BJA, Nagelkerken I, van der Velde G (2002) Post-settlement life cycle migration patterns and habitat preference of coral reef fish that use seagrass and mangrove habitats as nurseries. Estuar Coast Shelf Sci 55:309-321

- Cocheret de la Morinière E, Pollux BJA, Nagelkerken I, Hemminga MA, Huiskes AHL, van der Velde G (2003) Ontogenetic dietary changes of coral reef fishes in the mangroveseagrass-reef continuum: stable isotopes and gut-content analysis. Mar Ecol Prog Ser 246:279-289

> Dahlgren CP, Kellison GT, Adams AJ, Gillanders BM and others (2006) Marine nurseries and effective juvenile habitats: concepts and applications. Mar Ecol Prog Ser 312: 291-295

> Dufour V, Pierre C, Rancher J (1998) Stable isotopes in fish otoliths discriminate between lagoonal and oceanic residents of Taiaro Atoll (Tuamotu Archipelago, French Polynesia). Coral Reefs 17:23-28

Elsdon TE, Wells BK, Campana SE, Gillanders BM and others (2008) Otolith chemistry to describe movements and lifehistory parameters of fishes: hypotheses, assumptions, limitations, and inferences. Oceanogr Mar Biol Annu Rev 46:297-330

> Fodrie FJ, Herzka SZ (2008) Tracking juvenile fish movement and nursery contribution within arid coastal embayments via otolith microchemistry. Mar Ecol Prog Ser 361:253-265

Forrester GE, Swearer SE (2002) Trace elements in otoliths indicate the use of open-coast versus bay nursery habitats 
by juvenile California halibut. Mar Ecol Prog Ser 241: 201-213

Gillanders BM (2002a) Connectivity between juvenile and adult fish populations: Do adults remain near their recruitment estuaries? Mar Ecol Prog Ser 240:215-223

Gillanders BM (2002b) Temporal and spatial variability in elemental composition of otoliths: implications for determining stock identity and connectivity of populations. Can J Fish Aquat Sci 59:669-679

Gillanders BM (2005) Using elemental chemistry of fish otoliths to determine connectivity between estuarine and coastal habitats. Estuar Coast Shelf Sci 64:47-57

Gillanders BM, Kingsford MJ (1996) Elements in otoliths may elucidate the contribution of estuarine recruitment to sustaining coastal reef populations of a temperate reef fish. Mar Ecol Prog Ser 141:13-20

Gillanders BM, Kingsford MJ (2000) Elemental fingerprints of otoliths of fish may distinguish estuarine nursery habitats. Mar Ecol Prog Ser 201:273-286

Gillanders BM, Able KW, Brown JA, Eggleston DB, Sheridan PF (2003) Evidence for connectivity between juvenile and adult habitats for mobile marine fauna: an important component of nurseries. Mar Ecol Prog Ser 247:281-295

Huxham M, Kimani E, Newton J, Augley DJ (2007) Stable isotope records from otoliths as tracers of fish migration in a mangrove system. J Fish Biol 70:1554-1567

Kalish JM (1989) Otolith microchemistry: validation of the effects of physiology, age and environment on otolith composition. J Exp Mar Biol Ecol 132:151-178

Kendall MS, Monaco ME, Buja KR, Christensen JD, Kruer CR, Finkbeiner M, Warner RA (2001) Methods used to map the benthic habitats of Puerto Rico and the U.S. Virgin Islands. In: Benthic habitats of Puerto Rico and the U.S. Virgin Islands. NOAA, National Ocean Service, National Centers for Coastal Ocean Science Biogeography Program, Silver Spring, MD. Available at: biogeo.nos.noaa.gov/projects/ mapping/caribbean/startup.htm

Kendall M, Takata L, Jensen O, Hillis-Starr Z, Monaco M (2005) An ecological characterization of the Salt River Bay National Historical Park and Ecological Preserve, U.S. Virgin Islands. NOAA, National Ocean Service, National Centers for Coastal Ocean Science, Tech Memo 14, Silver Spring, MD

Kieckbusch DK, Koch MS, Serafy JE, Anderson WT (2004) Trophic linkages among primary producers and consumers in fringing mangroves of subtropical lagoons. Bull Mar Sci 74:271-285

Kraus RT, Secor DH (2005) Application of the nursery-role hypothesis to an estuarine fish. Mar Ecol Prog Ser 291: 301-305

Lindeman KC (1997) Development of grunts and snappers of southeast Florida; crossshelf distributions and effects of beach management alternatives. PhD dissertation, University of Miami

Luo J, Serafy JE, Sponaugle S, Teare PB, Kieckbusch D (2009) Movement of gray snapper Lutjanus griseus among subtropical seagrass, mangrove, and coral reef habitats. Mar Ecol Prog Ser 380:255-269

Mateo I (2009) Assessing essential fish habitat and connectivity of temperate and tropical fish populations using otolith microchemistry and stable isotopes. PhD dissertation, University of Rhode Island, Kingston, RI

Mateo I, Tobias WJ (2001) Distribution of shallow water coral reef fishes on the northeast of St. Croix, USVI. Carib J Sci $37: 210-226$

Mateo I, Tobias WJ (2004) Survey of nearshore fish communities on tropical backreef lagoons on the southeastern coast of St. Croix. Caribb J Sci 40:327-343
McFarland WN, Brothers EB, Ogden JC, Shulman MJ, Bermingham EL, Kotchian-Prentiss NM (1985) Recruitment patterns in young French grunts, Haemulon flavolineatum (Haemulidae), at St. Croix, USVI. Fish Bull 83: 413-426

Millar RM (1987) Maximum likelihood estimation of mixed stock fishery composition. Can J Fish Aquat Sci 44: 583-590

> Millar RM (1990) Comparison of methods for estimating mixed stock fishery composition. Can J Fish Aquat Sci 47:2235-2241

Mumby PJ, Edwards AJ, Arias-Gonzalez JE, Lindeman KC and others (2004) Mangroves enhance the biomass of coral reef fish communities in the Caribbean. Nature 427: $533-536$

> Nagelkerken I, van der Velde G (2002) Do non-estuarine mangroves harbour higher densities of juvenile fish than adjacent shallow-water and coral reef habitats in Curaçao (Netherlands Antilles)? Mar Ecol Prog Ser 245:191-204

> Nagelkerken I, van der Velde G (2004) Relative importance of interlinked mangroves and seagrass beds as feeding habitats for juvenile reef fish on a Caribbean island. Mar Ecol Prog Ser 274:153-159

Nagelkerken I, Dorenbosch M, Verberk WCEP, Cocheret de la Morinière E, van der Velde G (2000a) Day-night shifts of fishes between shallow-water biotopes of a Caribbean bay, with emphasis on the nocturnal feeding of Haemulidae and Lutjanidae. Mar Ecol Prog Ser 194:55-64

> Nagelkerken I, Dorenbosch M, Verberk WCEP, Cocheret de la Morinière E, van der Velde G (2000b) Importance of shallow-water biotopes of a Caribbean bay for juvenile coral reef fishes: patterns in biotope association, community structure and spatial distribution. Mar Ecol Prog Ser 202:175-192

- Nagelkerken I, van der Velde G, Gorissen MW, Meijer GJ, van't Hof T, den Hartog C (2000c) Importance of mangroves, seagrass beds and the shallow coral reef as a nursery for important coral reef fishes, using a visual census technique. Estuar Coast Shelf Sci 51:31-44

Nakamura Y, Horinouchi M, Shibuno T, Tanaka Y and others (2008) Evidence of ontogenetic migration from mangroves to coral reefs by black-tail snapper Lutjanus fulvus: stable isotope approach. Mar Ecol Prog Ser 355:257-266

Ogden JC, Ehrlich PR (1977) The behavior of heterotypic resting schools of juvenile grunts (Pomadasyidae). Mar Biol 42:273-280

Pollux BJA, Verberk WCEP, Dorenbosch M, Cocheret de la Morinière E, Nagelkerken I, van der Velde G (2007) Habitat selection during settlement of three Caribbean coral reef fishes: indications for directed settlement to seagrass beds and mangroves. Limnol Oceanogr 52:903-907

> Proctor CH, Thresher RE, Gunn JS, Mills DJ, Harrowfield IR, Sie SH (1995) Stock structure of the southern bluefin tuna Thunnus maccoyii: an investigation based on probe microanalysis of otolith composition. Mar Biol 122: 511-526

Quinn GP, Keough MJ (2002) Experimental design and data analysis for biologists. Cambridge University Press, Cambridge

Rooker JR (1995) Feeding ecology of schoolmaster snapper, Lutjanus apodus (Walbaum), from southwestern Puerto Rico. Bull Mar Sci 56:881-894

Rooker JR, Dennis GD (1991) Diel, lunar and seasonal changes in a mangrove fish assemblage off southwestern Puerto Rico. Bull Mar Sci 49:684-698

Sadovy Y, Severin KP (1992) Trace elements in biogenic aragonite: correlation of body growth rate and strontium levels 
in the otoliths of the white grunt, Haemulon plumieri (Pisces: Haemulidae). Bull Mar Sci 50:237-257

Sadovy Y, Severin KP (1994) Elemental patterns in red hind (Epinephelus guttatus) otoliths from Bermuda and Puerto Rico reflect growth rate, not temperature. Can J Fish Aquat Sci 51:133-141

Sanchez-Jerez P, Gillanders BM, Kingsford MJ (2002) Spatial variability of trace elements in fish otoliths: comparison with dietary items and habitat constituents in seagrass meadows. J Fish Biol 61:801-821

Shaw JC II (1997) Otolith age validation and growth of the white grunt, Haemulon plumieri (Lacipede, 1801) in southwestern Puerto Rico. MS thesis, University of Rhode Island, Kingston, RI

Shulman MJ (1985) Recruitment of coral reef fishes: effects of distribution of predators and shelter. Ecology 66: 1056-1066

Shulman MJ, Ogden J (1987) What controls tropical reef fish populations: recruitment or benthic mortality? An example in the Caribbean reef fish Haemulon flavolineatum. Mar Ecol Prog Ser 39:233-242

Thompson R, Munro JL (1983) The biology, ecology and bionomics of Caribbean reef fishes: Lutjanidae (snappers). In: Munro JL (ed) Caribbean coral reef fishery resources. ICLARM Stud Rev 7, p 94-109

Thorrold SR, Jones CM, Campana SE, McLaren JW, Lam JWH (1998a) Trace element signatures in otoliths record natal river of juvenile American shad (Alosa sapidissima). Limnol Oceanogr 43:1826-1835

Editorial responsibility: Stylianos Somarakis, Heraklion, Greece
Thorrold SR, Jones CM, Swart PK, Targett TE (1998b) Accurate classification of juvenile weakfish Cynoscion regalis to estuarine nursery areas based on chemical signatures in otoliths. Mar Ecol Prog Ser 173:253-265

Thorrold SR, Latkoczy C, Swart PK, Jones CM (2001) Natal homing in a marine fish metapopulation. Science 291: 297-299

Thresher RE, Proctor CH, Gunn JS, Harrowfield IR (1994) An evaluation of electron-probe microanalysis of otoliths for stock delineation and identification of nursery areas in a southern temperate groundfish, Nemadactylus macropterus (Cheilodactylidae). Fish Bull 92: $817-840$

- Verweij MC, Nagelkerken I (2007) Short and long-term movement and site fidelity of juvenile Haemulidae in back-reef habitats of a Caribbean embayment. Hydrobiologia 592:257-270

Verweij MC, Nagelkerken I, Hol KEM, van den Beld AHJB, van der Velde G (2007) Space use of Lutjanus apodus including movement between a putative nursery and a coral reef. Bull Mar Sci 81:127-138

Verweij MC, Nagelkerken I, Hans I, Ruseler SM, Mason PRD (2008) Seagrass nurseries contribute to coral reef fish populations. Limnol Oceanogr 53:1540-1547

> Yamashita Y, Otake T, Yamada H (2000) Relative contributions from exposed inshore and estuarine nursery grounds to the recruitment of stone flounder, Platichthys bicoloratus, estimated using otolith $\mathrm{Sr}: \mathrm{Ca}$ ratios. Fish Oceanogr 9:316-327

Submitted: June 10, 2009; Accepted: December 1, 2009 Proofs received from author(s): February 22, 2010 